\title{
KOMUNIKASI INSTRUKSIONAL DALAM PROSES BELAJAR MENGAJAR (STUDI KASUS DI SMP ISLAM ASHOFA PEKANBARU)
}

\author{
Julis Suriani \\ Universitas Islam Negeri Sultan Syarif Khasim Riau \\ Email: julis.suriani@uin-suska.ac.id
}

\begin{abstract}
Abstrak
Kualitas hasil pendidikan sangat tergantung dari proses pelaksanaan pembelajaran, karena itu komunikasi instruksional atau komunikasi pendidikan sebagai dasar pengetauhuan tentang pentingnya komunikasi dalam proses belajar mengajar atau pendidikan menjadi sangat penting. Sumber data yang digunakan adalah data primer dan data sekunder dengan metode pengumpulan data melalui wawancara, angket, dokumentasi setelah data terkumpul penulis melakukan analisa data dengan metode kualitatif deskriptif dan data yang diperoleh melalui angket penulis menganalisanya dengan metode kualitatif deskriptif presentase yaitu menganalisa data secara apa adanya berdasarkan hasil penelitian kemudian disajikan dalam bentuk tabel dan diberi interpetasi dari frekuensi jawaban yang diberikan responden. Dari hasil penelitian menunjukkan guru-guru SMP Islam As-Shofa Pekanbaru didalam melakukan implementasi komunikasi instruksional dengan siswa mereka melibatkan media-media komunikasi instruksional,dan juga pengajaran yang senantiasa membelajarkan anak didik dengan tujuan mengubah pola pikir dan tingkah laku siswa kearah yang lebih baik
\end{abstract}

Kata kunci: Komunikasi, instruksi, belajar mengajar 


\section{Pendahuluan}

Era globalisasi saat ini khususnya negara yang sedang berkembang yaitu negara Indonesia, nilai-nilai pendidikan sangat dijunjung tinggi dan juga diperhatikan.Pendidikan merupakan sesuatu yang tidak bisa diukur nilainya.Untuk mencapai itu semua dibutuhkan sumber daya manusia yang memiliki kemampuan pengetauhuan dan kredibilitas yang tinggi.Sumber daya manusia yang berkualitas pada umumnya lahir melalui proses pendidikan yang baik dan dari institusi pendidikan yang bermutu. Disini penulis mencoba membahas lebih dalam tentang mutu pendidikan melalui proses belajar mengajar ditinjau dari sudut pandang komunikasi yang diterapkan.

Adapun yang dicita-citakan tidak akan dapat terwujud tanpa adanya komunikasi yang baik. Komunikasi penting peranannya dalam berinteraksi, apakah itu di lingkungan keluarga, masyarakat atau sekolah. Pada lingkungan sekolah, komunikasi haruslah jelas dan dapat dilaksanakan dengan sebaik mungkin supaya apa yang disampaikan guru dapat diterima dan dimengerti oleh seluruh siswa. Untuk mendapatkan kualitas pendidikan yang baik diperlukan tidak saja input siswa pembelajar dan pengajar yang baik tetapi juga dibutuhkan sebuah metode pembelajaran yang baik. Metode pembelajaran ini sangat terkait dengan teknik dan strategi pembelajaran, proses pembelajaran yang tepat disertai fasilitas pendidikan yang memadai.Salah satunya adalah penggunaan media pendidikan dengan fokus pada bidang komunikasi instruksional.
Media pendidikan merupakan suatu alat atau perantara yang berguna untuk memudahkan proses belajar mengajar, dalam rangka mengefektifkan komunikasi antara pengajar dan pembelajar. Hal ini sangat membantu guru dalam mengajar dan memudahkan murid menerima dan memahami proses pembelajaran. Proses ini membutuhkan pengajar yang profesional dan mampu menyelaraskan antara media pendidikan dan metode pendidikan yang sesuai. Dengan kemajuan teknologi, ilmu pengetahuan serta perubahan sikap masyarakat yang lebih positif diharapkan membawa pengaruh yang besar dalam bidang pendidikan. Hal ini akan mendorong setiap lembaga pendidikan untuk mengembangkan proses pembelajarannya sehingga lebih maju dengan memanfaatkan teknologi modern dan kemajuan ilmu pengetahuan sebagai media penyampaian materi pembelajaran atau media instruksional. Disinilah pentingnya memahami komunikasi instruksional secara rinci yang akan menjadikan tujuan pendidikan lebih mudah dicapai.

Untuk mencapai pendidikan tersebut seorang pengajar memberikan peran yang penting untuk mengantarkan keberhasilan siswa pembelajar.Oleh karenanya, dibutuhkan komunikasi yang baik antara pelaku pembelajaran baik pengajar maupun siswa pembelajar.Hal ini juga terjadi dalam pembelajaran di lingkup perguruan tinggi.Untuk menciptakan komunikasi yang baik dibutuhkan dosen yang profesional yang mampu menyeimbangkan antara media 
pembelajaran dan metode pengajaran yang tepat dalam penggunaan komunikasi instruksional yang sesuai sehingga informasi pembelajaran yang disampaikan dapat diterima para mahasiswa dengan baik.Hal inilah yang mendasari kenapa penelitian tentang komunikasi instruksional di dalam lingkup sekolah sangat diperlukan.

Di sekolah, figur guru merupakan pribadi kunci.Gurulah panutan bagi anak didik. Semua sikap dan perilaku guru akan dilihat, didengar, dan ditiru oleh anak didik. Guru mempunyai wewenang dan tanggung jawab untuk mendidikkan anak didik. Guru mempunyai hak otoritas untuk membimbing dan mengarahkan anak didik agar menjadi manusia yang berilmu pengetauhuan di masa depan (Djamarah,2008:105). Oleh karena itu guru harus memiliki kemampuan di dalam berkomunikasi yang akan membekali guru dalam melaksanakan tugas dan tanggung jawabnya sebagai pengajar.

Ditinjau dari prosesnya, belajar mengajar adalah komunikasi dalam arti kata bahwa dalam proses tersebut terlibat dua komponen yang terdiri atas manusia, yakni pengajar sebagai komunikator dan pelajar sebagai komunikan. Lazimnya pada tingkatan bawah dan menengah pengajar itu disebut guru sedangkan pelajar itu disebut murid. Pada tingkatan apapun, proses komunikasi antara pengajar dan pelajar itu pada hakikatnya sama saja. Perbedaannya hanyalah pada jenis pesan serta kualitas yang disampaikan oleh si pengajar kepada si pelajar (Efendy,2011:101).
Banyak pelajaran yang gagal karena keliru atau tidak tahu bagaimana melakukan pengajaran yang berkualitas. Kegagalan itu antara lain ditimbulkan oleh adanya anggapan guru bahwa semua siswa dalam satu kelas atau sebagai objek yang dapat dibentuk sekehendak guru. Adapun manfaat adanya komunikasi intruksional antara lain efek perubahan perilaku, yang terjadi sebagai hasil tindakan komunikasi intruksional, bisa dikontrol atau dikendalikan dengan baik. Berhasil tidaknya tujuan-tujuan instruksional yang telah ditetapkan paling tidak bisa dipantau melalui kegiatan evaluasi. Lebih-lebih apabila kegiatan instruksional ini sudah memanfaatkan jasa teknologi, seperti misalnya media instruksional, manfaatnya akan semakin nyata (Yusuf,2010:11).

Menurut A.W. Widjaya, pada umumnya komunikasi mempunyai beberapa tujuan :

1. Agar pesan yang disampaikan dapat dimengerti

Sebagai komunikator kita harus mampu menjelaskan kepada komunikan dengan tuntas sehingga mereka dapat menyerap pesan sesuai dengan apa yang diinginkan komunikator.

2. Sebagai alat untuk memahami orang lain

Tujuan disini lebih dititik beratkan kepada pemimpin atau seorang pejabat, sebagai pemimpin atau seorang pejabat, sebagai pemimpin harus mengetauhui dengan jelas aspirasi dari masyarakat. Dengan terjadinya peristiwa feed back dalam komunikasi, dapat diketauhui keinginan lawan. 
3. Agar gagasan dapat diterima orang lain

Komunikator harus berusaha agar gagasan dapat diterima oleh lawan bicara dengan menggunakan pendekatan persuasif tetapi bukan paksaan.Pendekatan persuasif biasanya dimulai dengan aspek kebutuhan lawan bicara terhadap suatu gagasan.

4. Menggerakkan orang lain untuk melakukan sesuatu

Kegiatan yang membutuhkan tindakan motorik. Namun yang perlu diingat bagaimana cara komunikator berbicara agar orang banyak termotivasi, terdorong untuk melakukan kegiatan tersebut ( Widjaya,1993:10-11).

Dari pendapat diatas dapat dilihat bahwa komunikasi itu mempunyai 3 tujuan yakni mengharapkan pengertian atau pemahaman dari lawan bicara, mencari dukungan atau sesuatu gagasan dan selanjutnya mendorong orang lain untuk berperilaku sesuai dengan apa yang diinginkan komunikator.

Tujuan pendidikan melalui proses belajar mengajar adalah khas atau khusus, yakni meningkatkan pengetauhuan seseorang mengenai suatu hal sehingga ia menguasainya. Tujuan pendidikan itu akan tercapai jika prosesnya komunikatif. Jika proses belajarnya tidak komunikatif, tak mungkin tujuan pendidikan itu dapat tercapai (Efendy,1990:101)

Menurut Hari Sudradjad (2005

: 17) pendidikan yang bermutu adalah pendidikan yang mampu menghasilkan lulusan yang memiliki kemampuan atau kompotensi, baik kompetensi akademik maupun kompetensi kejuruan, yang dilandasi oleh kompetensi personal dan sosial, serta nilai-nilai akhlak mulia, yang keseluruhannya merupakan kecakapan hidup (life skill), lebih lanjut Sudradjat megemukakan pendidikan bermutu adalah pendidikan yang mampu menghasilkan manusia seutuhnya (manusia paripurna) atau manusia dengan pribadi yang integral (integrated personality) yaitu mereka yang mampu mengintegralkan iman, ilmu, dan amal. Didalam penelitian ini sudah jelas bahwa SMP Islam AsShofa Pekanbaru adalah sekolah yang selalu mengedepankan basis iman dan taqwa.

Komunikasi instruksional sebagai salah satu implementasi yang sangat penting dalam proses belajar mengajar atau dalam hal pencapaian tujuan bersama sebuah sekolah ini .SMP Islam As-Shofa Pekanbaru sebagai salah satu sekolah yang tepat untuk dijadikan objek penelitian dalam melakukan pembahasan lebih lanjut tentang bentuk penerapan komunikasi intruksional.

Perkembangan yang

ditunjukkan oleh SMP Islam AsShofa Pekanbaru dalam mendapatkan reward atau penghargaan, selalu dilandasi dengan kinerja tenaga pengajar yang lebih banyak mengedepankan penerapan komunikasi intruksional sebagai satu metode yang paling efektif dalam proses belajar mengajar.

\section{Metode}

Metodologi penelitian yang digunakan dalam skripsi ini adalah metodologi deskriptif kualitatif dengan analisis yang berwujud keterangan dan uraian yang menggambarkan objek penelitian 
yang digambarkan dengan kalimat untuk memperoleh kesimpulan. Metode ini untuk membuat gambaran mengenai situasi atau kejadian (bungin: 2013). Sumber data diambil dari data sekunder dan data primer.

\section{Hasil dan Pembahasan}

1. Guru memiliki kredibilitas yang tinggi dalam pelaksanaan proses belajar mengajar

Peneliti meninjau, strategi guru SMP Islam As-Shofa dalam membangun kepercayaan siswasiswi mereka dalam proses belajar mengajar dengan apa yang dilakukan sudah cukup bagus. Karena sekolah itu adalah proses belajar mengajar yang merupakan inti dari citra sekolah yang merupakan aset terpenting dalam mewujudkankan mutu pendidikan yang bermutu.

Sesuai dengan teori Djamarah (2008:105) guru mempunyai hak ototritas untuk membimbing dan mengarahkan anak didik agar menjadi manusia yang berilmu pengetauhuan di masa depan. dan diperkuat lagi dengan teori widjaya (1993:25-

26) dimana guru harus mampu menginformasikan komunikasi yang menyentuh ( persuasif) dan penguasaan ilmu retorika yang menggugah.

2. Guru menyiapkan materi pelajaran

Dengan melihat persiapan materi pelajaran yang dilakukan oleh guru SMP Islam As-Shofa Pekanbaru sebelum melakukan kegiatan proses belajar mengajar sebagaimana yang dipaparkan Nur Azizah selaku guru Bahasa Inggris memang sudah cukup baik, yakni dengan paparan sebelum melakukan proses belajar mengajar, persiapan selain menyiapkan materi pelajaran yang akan disampaikan biasanya persiapan metode atau media belajar, seperti dalam menggunakan power point. Guru itu mempersiapkan soundsystem, papan layar, laptop dan itu semua sudah ada di setiap kelas. Tinggal guru nya saja. Sehingga proses belajar tersebut menjadi terarah. Sesuai dengan teori Rosida (102002) bahwasanya efektifitas komunikasi instruksional yang menggunakan alat lejaran atau media erat hubungannya dengan cara belajar siswa. Dan hal itu telah dimiliki oleh guru SMP Islam As-Shofa.

3. Guru menyampaikan materi pelajaran kepada anak didik yaitu siswa

Pada hakikatnya guru merupakan komunikator. Yang memberikan informasi kepada anak didik sesuai dengan paparan dibawah ini:

\section{Biasanya}

cara menyampaikan materi pelajaran kepada anak didik itu selain dengan metode tanya jawab, ceramah, kita juga menggunakan metode Drill yakni mengajar dengan mengadakan latihanlatihan dengan jalah melatih anakanak terhadap bahan pelajaran yang sudah diberikan dan ditunjang dengan media-media instruksional sehingga anak itu memiliki kecakapan dalam belajar. Cara-cara menyampaikan materi yakni dengan melakukan percobaan, misalnya kami menampilkan yang nyata atau 
abstrak. Contoh pada mata pelajaran matematika kita selalu membawa alat peraga misalnya membawa timbangan berat badan dikelas, kubus, balok dan masih banyak lagi. Itulah salah satu cara penyampaian materi kita, tergantung bidang stduy juga yang terpenting bagaimana ilmu itu dapat di transfer dengan baik kepada anak. insyaALLAH guruguru disini cukup aktif lah dengan teknik pengajaran tidak pernah mati dengan tidak adanya alat peraga contoh meja belajar, lantai yang dijadikan objek belajar yang penting kita gak boleh kaku.

Efendy (2011:101) juga

mengatakan ditinjau dari prosesnya, belajar mengajar adalah komunikasi dalam arti kata bahwa dalam proses tersebut terlibat dua komponen yang terdiri atas manusia, yakni pengajar sebagai komunikator dan pelajar sebagai komunikan. Lazimnya pada tingkatan bawah dan menengah pengajar itu disebut guru sedangkan pelajar itu disebut murid. Pada tingkatan apapun, proses komunikasi antara pengajar dan pelajar itu pada hakikatnya sama saja. Perbedaannya hanyalah pada jenis pesan serta kualitas yang disampaikan oleh si pengajar kepada si pelajar.

4. Materi yang disampaikan oleh guru dalam bentuk lisan berupa pengajaran, pelajaran, dan pembelajaran

Berdasarkan hasil wawancara dari guru bahasa inggris yang memaparkan berbentuk lisan tentunya berupa pengajaran, dan pelajaran kepada anak didik karena guru sebagai komunikator disini yakni selain memberikan materi ingin mengubah pola pikir anak didik agar jauh kedepan lebih baik.

Unsur sumber (who) merangsang pertanyaan mengenai pengendalian pesan, sedangkan unsur pesan (says what) merupakan bahan analisis isi.Saluran komunikasi (in which channel) dikaji dalam analisis media.Unsur Penerima (to whom) dikaitkan dengan analisis khalayak, sementara unsur pengaruh (with what effect) jelas berhubungan dengan studi mengenai akibat yang ditimbulkan pesan (Mulyana, 2005:137).

Maka dalam penelitian ini dapat penulis jelaskan bahwasanya who adalah guru, says what adalah materi atau pesan, in which chanell adalah saluran komunikasi yang digunakan oleh guru dalam proses belajar mengajar, to whom adalah murid yang melakukan proses belajar, sedangkan with what efect adalah Pengaruh atau hasil proses belajar mengajar melalui komunikasi intruksional.

5. Cara penyampaian materi guru menggunakan metode atau media instruksional

Peneliti meninjau, cara penyampaian pesan atau materi yang dilakukan guru SMP Islam As-Shofa pekanbaru memang telah melibatkan media-media instruksional yang memadai dalam menunjang kegiatan proses belajar mengajar. Baik media cetak dan media elektronik, dan terlihat sekali proses komunikasi instruksional sangat terjadi di SMP Islam As-Shofa Pekanbaru. 
6. Siswa suka dalam menerima

pelajaran yang telah disampaikan

\begin{tabular}{|c|c|c|c|}
\hline $\mathrm{O}$ & $\begin{array}{l}\quad \text { Al } \\
\text { ternatif } \\
\text { Jawaba } \\
n\end{array}$ & $\begin{array}{l}\text { J } \\
\text { umlah } \\
\text { (oran } \\
\text { g) }\end{array}$ & $\begin{array}{r}\text { Pres } \\
\text { entase }(\%)\end{array}$ \\
\hline . & $\begin{array}{lr}\text { rius } & \text { Se } \\
& H \\
\text { umoris } \\
\text { B } \\
\text { ercerita } \\
\text { Pr } \\
\text { aktik }\end{array}$ & $\begin{array}{ll} & 3 \\
& 2 \\
3 & \\
& 1 \\
& \\
0 & \\
& 8\end{array}$ & $\begin{array}{l}6,8 \\
52,3 \\
22,7 \\
18,2\end{array}$ \\
\hline & $\begin{array}{ll} & \mathrm{T} \\
\text { otal } & \end{array}$ & $\begin{array}{l}4 \\
4 \\
\text { orang }\end{array}$ & 100 \\
\hline
\end{tabular}

oleh guru

\section{TABEL 5}

Senang dalam menerima materi pelajaran yang diajarkan

\begin{tabular}{|c|c|c|c|}
\hline $\begin{array}{l}\mathrm{N} \\
\mathrm{O}\end{array}$ & $\begin{array}{l}\text { Alternat } \\
\text { if } \\
\text { Jawaba } \\
n\end{array}$ & $\begin{array}{l}\text { Jumla } \\
\text { h } \\
\text { (oran } \\
\text { g) }\end{array}$ & $\begin{array}{l}\text { Presentase ( } \\
\%)\end{array}$ \\
\hline $\begin{array}{l}\text { a. } \\
\text { b. } \\
\text { c. } \\
\text { d. }\end{array}$ & $\begin{array}{l}\text { Sangat } \\
\text { senang } \\
\text { Senang } \\
\text { Cukup } \\
\text { senang } \\
\text { Tidak } \\
\text { senang }\end{array}$ & $\begin{array}{l}14 \\
24 \\
6 \\
-\end{array}$ & $\begin{array}{l}31,8 \\
54,5 \\
13,7 \\
-\end{array}$ \\
\hline & Total & $\begin{array}{l}44 \\
\text { orang }\end{array}$ & 100 \\
\hline
\end{tabular}

Dari tabel diatas dapat diketauhui bahwa siswa yang berjumlah 44 orang, yang sangat senang menerima pelajaran dari guru berjumlah 14 orang $(31,8 \%)$, senang berjumlah 24 orang $(54,5 \%)$, cukup senang berjumlah 6 orang $(13,7 \%)$, dan tidak ada siswa yang tidak senang menerima pelajaran yang diajarkan oleh guru.

TABEL 6
Gaya Mengajar Guru

Dari tabel diatas dapat dilihat bahwa gaya mengajar guru yang disukai siswa dominan humoris. Hal ini terlihat dari tabel di atas bahwa hanya 3 orang $(6,8 \%)$ siswa yang menyukai gaya mengajar serius, sedangkan yang menyukai humoris 23 orang $(52,3 \%)$, yang menyukai bercerita 10 orang $(22,7 \%)$, dan praktik 8 orang $(18,2 \%)$.

7. Partisipasi siswa dalam proses belajar mengajar

TABEL 7

Partisipasi Siswa Dalam Proses

Belajar Mengajar

\begin{tabular}{|c|c|c|c|}
\hline $\mathrm{O}$ & $\begin{array}{l}\text { Alternatif } \\
\text { Jawaban }\end{array}$ & $\begin{array}{l}\text { umla } \\
\text { h } \\
\text { (oran } \\
\text { g) }\end{array}$ & $\begin{array}{r}\text { Pres } \\
\text { entase }(\%)\end{array}$ \\
\hline . & $\begin{array}{l}\text { Ya, } \\
\text { berpartisi } \\
\text { pasi } \\
\text { Tid } \\
\text { ak } \\
\text { berpartisi } \\
\text { pasi }\end{array}$ & 0 & $\begin{array}{l}90,9 \\
9,1\end{array}$ \\
\hline & al Tot & $\begin{array}{l}4 \\
\text { oran } \\
\mathrm{g}\end{array}$ & \\
\hline
\end{tabular}

Dari tabel diatas dapat dilihat bahwa siswa yang berpartisipasi dalam proses belajar mengajar 40 orang $(90,9 \%)$ dan siswa yang tidak berpartisipasi berjumlah 4 orang ( 9,1). Jadi kesimpulan nya ialah komunikasi instruksional yang dilakukan guru SMP Islam As-Shofa Pekanbaru dalam proses belajar mengajar sangat baik, karena adanya feedback dari siswa atau komunikan. 
Dan bentuk dari partisipasi mereka dapat kita lihat pada tabel dibawah ini.

TABEL 8

Bentuk Partisipasi Siswa Dalam proses Belajar Mengajar

\begin{tabular}{|c|c|c|c|}
\hline $\mathrm{O}$ & $\begin{array}{l}\text { Al } \\
\text { ternatif } \\
\text { Jawaban }\end{array}$ & $\begin{array}{l}\quad \text { J } \\
\text { umlah } \\
\text { (oran } \\
\text { g) }\end{array}$ & $\begin{array}{l}\text { Prese } \\
\text { ntase }(\%)\end{array}$ \\
\hline • & \begin{tabular}{l} 
skusi $^{\text {Di }}$ Ta \\
nya- $^{\text {jawab }}$ \\
\multicolumn{2}{c}{$\operatorname{Pr}$} \\
aktik \\
\multicolumn{2}{c}{ O } \\
bservasi \\
lapanga \\
n Ti \\
dak \\
menjaw \\
ab
\end{tabular} & $\begin{array}{ll} & 1 \\
5 & \\
& 1 \\
0 & \\
& 1 \\
5 & \\
& 4 \\
& \\
& -\end{array}$ & $\begin{array}{l}34,1 \\
22,7 \\
34,1 \\
9,1 \\
-\end{array}$ \\
\hline & $\begin{array}{ll} & \text { To } \\
\text { tal } & \end{array}$ & $\begin{array}{l}4 \\
4 \\
\text { orang }\end{array}$ & \\
\hline
\end{tabular}

Dari tabel diatas dapat dilihat bahwa bentuk partisipasi siswa dalam proses belajar mengajar yang memilih diskusi berjumlah 15 orang $(34,1 \%)$, tanya jawab berjumlah 10 orang $(22,7 \%)$, praktik berjumlah 15 orang $(34,1 \%)$, observasi lapangan berjumlah 4 orang $(9,1 \%)$ dan tidak ada siswa yang tidak menjawab mengenai bentuk partisipasi mereka dalam proses belajar mengajar di kelas.

Dari hasil presentase pada tabel dapat penulis analisa bahwa bentuk partisipasi siswa dalam proses belajar mengajar ditunjukkan dengan bentuk diskusi dan praktik.
Diskusi ialah

Praktik disebut juga dengan istilah demionstrasi yaitu dalam pengajaran dipakai untuk mengambarkan suatu cara mengajar atau siswa sekalipun memperlihatkan kepada seluruh kelas suatu proses pengoperasian peralatan barang atau benda (Ramayulis,2008:281).

Tanya- jawab adalah suatu cara yang terjadi dalam proses belajar mengajar dimana guru dan murid aktif, bersama, guru bertanya murid mencari jawaban, murid mengemukakan ide baru (Roestiyah,1989:70). Sedangkan observasi lapangan menurut Ramayulis (2008: 285) ialah seorang peserta didik melakukan pengamatan setiap hasil percobaan diamati oleh peserta didik.

Tabel 9

Sumber Informasi Pelajaran Siswa

\begin{tabular}{|c|c|c|c|}
\hline $\mathrm{O}$ & $\begin{array}{l}\text { A } \\
\text { lternatif } \\
\text { Jawaba } \\
n\end{array}$ & $\begin{array}{l}\text { umlah } \\
\text { (oran } \\
\text { g) }\end{array}$ & $\begin{array}{l}\text { Prese } \\
\text { ntase }(\%)\end{array}$ \\
\hline $\begin{array}{l}\text {. } \\
. \\
\text {. } \\
\text {. }\end{array}$ & \begin{tabular}{lr} 
& G \\
uru & \\
uku & B \\
\multicolumn{2}{c}{ In } \\
ternet \\
\multicolumn{2}{c}{ Th } \\
elevisi \\
oran
\end{tabular} & $\begin{array}{ll} & 2 \\
2 & \\
& 6 \\
& 1 \\
1 & \end{array}$ & $\begin{array}{l}50 \\
13,6 \\
25 \\
11,4 \\
-\end{array}$ \\
\hline & $\begin{array}{ll}\text { otal } & \mathrm{T}\end{array}$ & $\begin{array}{l}\quad 4 \\
4 \\
\text { orang }\end{array}$ & \\
\hline
\end{tabular}

Dari tabel diatas dapat dilihat bahwa sumber informasi siswa dalam proses belajar mengajar, yang 
memilih guru berjumlah 22 orang $(50 \%)$, buku berjumlah 6 orang $(13,6)$, internet berjumlah 11 orang (25\%), televisi berjumlah 5 orang $(11,4 \%)$ dan tidak ada siswa yang memilih koran sebagai sumber informasi.

8. Dapat berpengaruh terhadap perilaku siswa, dari tidak baik menjadi baik dan dari tidak tau menjadi tau

Berdasarkan hasil wawancara yang diperoleh memang benar implementasi komunikasi instruksional atau komunikasi pendidikan memberikan pengaruh besar terhadap akhlak siswa dan pengetauhuannya. Hal itu didukung dari teori bahwasanya dalam hal ini bukan hanya penyampaian pesan berupa materi pelajaran melainkan penanaman sikap dan nilai pada siswa yang belajar (hamalik,2009:10).

9. Nilai rapor siswa sangat menentukan keberhasilan dari proses belajar mengajar

Hasil dari proses belajar mengajar salah satunya dapat dilihat dari nilai rapor siswa. Inilah hasil akhir dari implementasi komunikasi instruksional. Proses dalam pengertiannya di sini merupakan interaksi semua komponen atau unsur yang terdapat dalam belajar mengajar antara lain tujuan instruksional yang hendak dicapai, materi pelajaran, metode mengajar, alat peraga pengajaran, dan evaluasi sebagai alat ukur tercapai tidaknya tujuan komunikasi instruksional yang dilakukan oleh guru SMP Islam AsShofa Pekanbaru.

\section{Simpulan}

Berdasarkan hasil penelitian yang penulis lakukan untuk melihat bagaimana implementasi komunikasi instruksional dalam proses belajar mengajar di SMP Islam As-Shofa pekanbaru, maka dapat ditarik kesimpulan bahwa implementasi komunikasi instruksional guru dalam proses belajar mengajar di SMP Islam As-Shofa telah menggunakan bentuk-bentuk komunikasi instruksional yang baik. Diantaranya dalam menyampaikan materi pelajaran telah menggunakan mediamedia instruksional seperti penggunaan infocus, power point, sound system, dan sarana prasarana lainnya.Dan siswa juga senang menerima pelajaran yang disampaikan oleh guru, dari hasil penyebaran angket.

Berdasarkan penelitian yang telah dilakukan, maka penulis dapat menyimpulkan bahwa:

1. Pelaksanaan komunikasi instruksional yang dilakukan oleh guru dalam proses belajar mengajar sangat baik, hal ini ditandai dengan seperti guru menyiapkan materi pelajaran sebelum memulai proses belajar mengajar, guru bertindak langsung dalam memberikan informasi atau materi pelajaran yang dari tidak tau menjadi tau dan guru SMP Islam As-Shofa selalu berusaha untuk mengubah pola pikir siswa kearah yang lebih baik.

2. Dapat ditarik kesimpulan bahwa proses belajar mengajar tentunya berisi pengajaran dan pelajaran dengan tujuan memberikan materi pelajaran dan juga mengubah perilaku siswa.

3. Komunikasi pendidikan atau komunikasi instruksional yang 
dilakukan oleh guru SMP Islam As-Shofa tidak hanya bertujuan memberikan informasi atau pengajaran tetapi juga membelajarkan peserta didik.

4. Komunikasi instruksional yang dilakukan oleh guru SMP Islam As-Shofa telah melibatkan mediamedia instruksional, hal ini merupakan salah satu faktor bagi peserta didik untuk melek informasi.

\section{Saran}

Sebagai tulisan penutup, penulis menyampaikan beberapa saran kepada pihak - pihak yang terlibat dalam upaya mensukseskan program komunikasi dalam pengajaran di SMP Islam As-Shofa Pekanbaru yakni:

Agar komunikasi instruksional guru lebih efektif perlu dilakukan hal-hal berikut:

1. Guru diharapkan lebih berupaya untuk meningkatkan profesionalisme dalam menerapkan keterampilan memaparkan materi pelajaran terhadap siswa agar dapat lebih baik dimengerti.

2. Siswa diharapkan dapat menumbuhkan perhatian dan kemauan untuk mengerti dengan penyampaian materi oleh guru.

3. Penyampaian materi oleh guru disajikan dengan lebih menarik, diselingi beberapa humor yang fresh dan menghibur untuk menjaga perhatian siswa-siswi.

4. Perlu adanya komunikasi untuk mengetahui sasaran pembelajaran guru maupun target siswa-siswi dalam pembelajaran dengan lebih jelas dan tidak hanya pada sisi guru saja.
5. Materi yang disampaikan pada saat proses belajar mengajar dapat diaplikasikan dalam kehidupan sehari-hari siswa-siswi sehingga tidak terlalu textbook saja. Selain tercermin dalam perilaku seharihari, nilai pembelajaran juga tecermin dalam cara pikir siswasiswi yang lebih ilmiah.

\section{Referensi}

Anwar, Arifin. Ilmu Komunikasi. Rajawali Press. Jakarta, 1992

Arikunto, Suharsimi. Prosedur Penelitian Suatu Pendekatan Praktek. Rinekka Cipta. Jakarta, 1998

Arikunto, Suharsimi. Prosedur Penelitian Suatu Pendekatan Praktek. Cetakan ketiga.Rinekka Cipta. Jakarta, 2006

Bahri, Syaiful,Zain, Azwan. Strategi Belajar Mengajar. Rineka Cipta. Jakarta,2002

Canggara, Hafied. Pengantar Ilmu Komunikasi. Raja Grafindo Persada. Jakarta, 2008

Djamarah,Bahri, Syaiful. Psikologi Belajar. Rineka Cipta. Jakarta,2008

Efendy, Ujhana Onong. Komunikasi Pengantar. PT. Remaja Rosdakarya-Bandung, $\quad 1990$

Komunikasi Teori dan Praktek. PT. Remaja Rosdakarya-Bandung, 2011 Hamalik, Oemar. Proses Belajar Mengajar.PT. Bumi Aksara. Jakarta, 2009

Liliweri, Alo. Sosiologi Organisasi. PT. Citra Aditya Bakti.Bandung, 1997 mukhrin Dkk. Pedoman Mengajar.Al-Ikhlas. Surabaya,1981. 
Muhammad. Guru Dalam Proses Belajar Mengajar. Sinar Baru Algensindo. Bandung, 1997

Mulyana, Dedy. Ilmu Komunikasi Suatu Pengantar. Penerbit PT. Remaja Rosda Karya. Bandung,2005.

Mulyana, Dedy. Ilmu Komunikasi Suatu Pengantar. Penerbit PT. Remaja Rosda Karya. Bandung,2000.

M. Yusuf, Pawit. Komunikasi Pendidikan dan Komunikasi Instruksional. PT. Remaja Rosda Karya. Bandung, 1990

M. Yusuf, Pawit . Komunikasi Instruksional Teori dan Praktek. Bumi Aksara. Jakarta.2011

Poewardaminta. W.J.S. Kamus Umum Bahasa Indonesia. Balai Pustaka, Jakarta.1985
Rosidah.Efektifitas Komunikasi Intruksional Guru Di SMKN 3 Pekanbaru(skripsi).2002

Rakhmat, Jalaluddin. Metode Penelitian Komunikasi. PT. Remaja Rosdakarya. Bandung, 2009

Ruslan, Rosady. Metode Penelitian Public Relation dan Komunikasi.Raja Grafindo Persada. Jakarta, 2003

Slameto.Proses Belajar Mengajar Dalam Sistem Kredit Semester (SKS). Bumi Aksara. Jakarta:1991

Wardani, IGAK. (2005). Dasar-Dasar Komunikasi dan Keterampilan Dasar Mengajar. PAU-DIKTI DIKNAS. Jakarta.

Widjaya, A.W. Komunikasi, Bumi Aksara. Jakarta. 1993 